A. D. E. F. refer to the rolls in the Harleian MSS. in which the coats are found.

I like to imagine the old man "when the bell till'd, to use the Salisbury frase, to evening prayers," sitting in his seat in the Cathedral-

"Where through the long-drawn aisle and fretted vault

The pealing anthem swells the note of praise."

listening to the longwinded sermons of perhaps his friend Bishop Seth Ward, and pondering maybe on some of the illustrious figures of the past connected with the City and Cathedral. Of William of the Long Sword, the warrior Earl of Salisbury; and Bishop Roger, the Grand Justiciar, who, on the authority of Bishop Stubbs, owed his rise to favour and his place in the confidence of Henry the First, to the expeditious way in which he got through divine service; and wishing probably that his successors in the throne at Salisbury had followed his example in this respect.

In conclusion I must express my best thanks to Miss Targett of Salisbury and to Mr. J. J. Hammond, Clerk to the Dean and Chapter for much assistance, particularly to $\mathrm{Mr}$. Hammond for references and much local help; to my brother, the hon. Librarian of Southwell Cathedral, for the heraldic notes and to Mr. Gibbons for the abstract of the will.

\title{
REFERENCES
}

1. Foster's "Alumni Oxonienses," 1st series, Vol. IV.

2. James, R. R.-Sir William Read. Trans. Ophthal. Soc. of the U.K., Vol. XLI, p. 342.

3. Hirschberg, J. - Geschichte der Augenheilk., in Graefe Saemisoh Handbuch. Vol. XIV, Chap. 23, p. 118. 1911.

\section{REPORT ON THE CASES OF GLIOMA RETINAE TREATED AT THE ROYAL LONDON OPHTHALMIC HOSPITAL DURING THE YEARS I915-1924}

Bx

\author{
R. C. Davenport \\ MOORFIELDS RESEARCH SCHOLAR
}

IN 1890 Lawford and Collins published in the Royal London Ophthalmic Hospital Reports (Volume XIII) a review of the cases of glioma retinae treated in the hospital from the year 1871 .

This record has been kept up by Marshall (Volume XIV), Owen (Volume XVI), Berrisford (Volume XX) bringing it to the year 1915. The following paper brings it up to 1924 .

During the 10 years, 1915-1924, there were $2 \tau$ cases of glioma retinae treated in the hospital. All these were proved by microscopic examination, and they bring the total since 1871 to 163 . 
Sex. Males 16 ; females 11.

Eyes involved. Bilateral 5, viz. 18.5 per cent.; R. 7 ; L. 15.

Of the bilateral cases 3 had excision of both globes and of these two are known to be alive and the third may be presumed to be alive 10 years after removal of the second eye, for, though the case cannot be traced, there is no death record at the General Register Office. One case (of unusual interest-to be referred to again below) is reported very well 7 years after the second eye was removed and the other $2 \frac{1}{2}$ years.

Age when any lesion was first noted. It is not possible to be quite certain in several cases of this date but as far as can be judged, the following are the ages of the children when anything amiss was noticed :

Birth, $1 ; 1$ to 3 months, $1 ; 4$ to 6 months, $2 ; 7$ to 12 months, 6 ; 1 to 2 years, $4 ; 2$ to 3 years, $5 ; 3$ to 4 years, $3 ; 4$ to 5 years, 4 ; 7 years, 1.

With regard to the date at which the second eye was involved: 2 were bilateral when the case was first seen. One was noted within 12 months after the first eye was removed; 1 was noted within 13-14 years after the first eye was removed (see below).

Mortality and Recovery. Of the 27 cases 8 are known to be dead, 12 are known to be alive, and 7 cannot be definitely ascertained. Of these, 3 have been seen one year after operation and found free from recurrence and in all the 7 cases there can be found no death record at the General Register Office.

In the cases known and presumed alive the following periods have elapsed since removal of the growth in each case.

\begin{tabular}{|c|c|c|c|c|c|}
\hline & $\begin{array}{l}\text { Case } \\
\text { No. }\end{array}$ & & & & Years \\
\hline & 5 & $\ldots$ & $\ldots$ & $\ldots$ & 10 \\
\hline & 8 & $\ldots$ & $\ldots$ & $\ldots$ & $9 \frac{9}{12}$ \\
\hline & 9 & $\ldots$ & $\ldots$ & ... & 8 \\
\hline & 19 & $\ldots$ & $\ldots$ & $\ldots$ & 7 \\
\hline & 3 & $\ldots$ & $\ldots$ & $\ldots$ & 6 \\
\hline known & 16 & $\ldots$ & $\ldots$ & ... & $4_{1}^{\frac{9}{2}}$ \\
\hline alive & 23 & $\ldots$ & $\ldots$ & $\ldots$ & 3 \\
\hline & 12 & $\ldots$ & $\ldots$ & ... & $2 \frac{8}{12}$ \\
\hline & 21 & $\ldots$ & $\ldots$ & $\ldots$ & $2 \frac{5}{12}$ \\
\hline & 25 & $\ldots$ & $\ldots$ & $\ldots$ & 2 \\
\hline & 18 & $\ldots$ & $\ldots$ & $\ldots$ & 1 \\
\hline & 27 & $\ldots$ & $\ldots$ & ... & 1 \\
\hline & 11 & $\cdots$ & $\cdots$ & $\cdots$ & 10 \\
\hline & 13 & $\ldots$ & $\ldots$ & ... & 10 \\
\hline & 4 & $\ldots$ & $\ldots$ & $\cdots$ & $9 \frac{1}{2}$ \\
\hline $\begin{array}{l}\text { resumed } \\
\text { alive }\end{array}$ & 14 & lear 1 & year a & & 6 \\
\hline & 7 & & year a & & $4 \frac{1}{2}$ \\
\hline & $\begin{array}{l}22 \\
24\end{array}$ & ear & vear & & $\begin{array}{l}3 \\
3\end{array}$ \\
\hline
\end{tabular}


As three years is given as the safety limit for freedom from recurrence it will be seen that 7 cases may be regarded as known "cured," while to that number can most probably be added some from the remainder not known to have died from recurrence.

Of the fatal cases 2 were bilateral-the others unilateral. The length of time there was a lesion suspected by the parents varied, but on the whole the cases were brought to hospital much later than the average as can be judged by scanty histories. In several cases no action was taken for several months-in some till the redness and pain of increased tension in the eye obviously acted as a stimulus to the seeking of advice.

In only 17 cases are the end results and histories both sufficiently certain to give figures.

Of 8 fatal cases a lesion was noticed (on average) for 13 months. Of 9 "cured" cases a lesion was noticed (on average) for 3 months.

The fatal cases include 2 where the condition was bilateral and the parents were convinced only after long delay that excision of the second eye was advisable. Leaving out these two the average still remains high, viz., 10 months.

The length of life after the appearance of the signs varied from a few months-about 9-12-to a much longer period; 2 cases surviving for over 3 years after the eye was known to have contained a glioma growth, operation being delayed till shortly before death. In all the fatal cases where a globe that was not obviously externally involved, was excised, the optic nerve at its point of division was microscopically shown to be invaded by cells of the glioma. In no case that recovered was the nerve found involved. Only one case died in hospital and no autopsy was possible. The cause of death was meningitis following the removal of a large fungating mass from the orbit of a child whose other globe had been removed 2 years previously for a glioma verified by section.

One case of recurrence was admitted to a hospital for children in London and there died. The autopsy showed extensive backward spread of the growth into the brain with a deposit at the back of the other orbit.

In no case has there been any true evidence of glioma in a shrunken globe with or without glioma in the other eye. The bilateral cases (with the exception of the case to be mentioned later) have shown typical progress in the second eye. One is of some interest (No. 21) where both eyes were found involved in 1921. The left was excised and right excision advised, but declined by the parents who took the child to another hospital. Here it was watched till June, 1923, when the globe was so full of growth and likely to rupture that the parents consented to 
removal of the eye. This was done then and the child is reported free from recurrence-now $2 \frac{1}{2}$ years later -a somewhat remarkable feature.

One case of especial interest is found in the series and has been reported by Maghy (Brit. Jl. of Ophthal., August, 1919). Briefly, the right eye was excised at the Royal London Ophthalmic Hospital at the age of 2 years in 1900 for a glioma-proved microscopically-and not invading the optic nerve. The child was reported well in 1905 - the left eye apparently normal according to the local doctor's report. In 1913 the girl had a series of "fits" lasting over a period of three months and on Christmas Dav of that year suddenly "went blind" in her left eye. This remained so and she was treated under the local doctor till October when she was admitted to hospital the eye being in a state of secondary glaucoma with an opaque lens. As projection was accurate linear extraction was performed successfully, but later the tension became raised again and exudate appeared in the anterior chamber, and at this time the nasal field was found defective. After several operations, chiefly for increased tension, the eye settled down and when discharged in March, 1915, the vision was 6/60 with a plus 12.0D. sphere. Later, vision declined and tension rose at intervals and despite many operations to control it, remained high, and subsequently on account of severe pain the eye was excised in May, 1918 (almost 18 years after the first eye), and on section was found to contain a growth, beyond doubt a glioma retinae. This, in spite of its presumed early existence, had not got beyond the globe and now the girl (7 years later) is reported to be very well and, free from trouble in either socket, is wearing two artificial eyes.

The history of this case appears unique as differing from any case in which a glioma was found in an eye which had become shrunken at or near the time the fellow eye had a glioma within it. Here the eye was apparently normal for 13-14 years, and then began a $4 \frac{1}{2}$ years' history of increased tension and failure which ended in the proved existence of a glioma retinae. The globe never shrank at all, but the long history subsequent to 1914 suggests that either temporary retrogressions may have occurred or else that its malignancy was unusually low perhaps because of the age of the patient. There was no sign of extra-ocular extension nor has there been any recurrence.

Pathological Findings. All the eyes have been submitted to examination and proved true gliomata. In one case no section was cut off the growth owing to its extensive calcification from degeneration. Macroscopically it was typical in appearance, and the fact that anything amiss with the eye had been noticed only four months makes the extensive calcification somewhat unusual. 
No recurrence has taken place since the excision of the eye ten years ago and the child is reported perfectly well.

Family History. In no case was there any evidence of a familial or hereditary tendency to glioma retinae.

I wish to thank the members of the surgical staff at Moorfields for the permission to make use of their case records and the facilities given me as Research Scholar to collect the details shown in this paper.

\title{
THE AFTER RESULTS OF CORNEO-SCLERAL TREPHINING FOR GLAUCOMA
}

BY

\author{
R. C. DAVENPORT \\ MOORFIELDS RESEARCH SCHOLAR
}

THE following paper is made up entirely on examination of the results of the corneo-scleral trephine operations performed at Moorfields by the present surgical staff during the five years 1919-1923.

All those cases where the records are available have been included and probably the numbers represent almost all such operations done.

The review is presented quite candidly with no bias for or against the operation. The records kept were nade in the usual rush of the hospital's work, and not with a view to criticai examination later. Accordingly, in many cases they lack of necessity the completeness that a critical examination might desire. Many of them cease abruptly so that the result can only be judged at a point shortly after operation. Others are carried on for some years from operation and thus are of greater value. It is true that the latter are mostly those in which vision was grossly impaired at operation-a fact which has presumably made the patient more zealous in attendance so that further decline might be guarded against if possible. The early glaucoma case with good vision ceases attendance, in many cases, soon after a successful operation, and it seems justifiable to suppose the success of the operation to be prolonged, if not actually total, where the patient does not return to complain of any departure from the satisfactory condition noted soon after operation.

In judging the effects of the operations it has been necessary to rely, as said before, on scanty records. These embrace chiefly the tension of the eye to fingers and the visual acuity. Perimetric records have been far too limited to be used in judgment; indeed where the vision has remained as before the operation and essentially full, and the tension normal, the fields have not, as a rule, been charted, and the few that are shown do not suggest 